\title{
The differential diagnosis of the short-limbed dwarfs presenting at birth
}

\author{
R. N. MUKHERJI \\ M.R.C.P., D.C.H.
}

\author{
P. D. Moss \\ F.R.C.P., D.C.H.
}

\author{
Department of Paediatrics, Royal Infirmary, Blackburn, Lancashire
}

\begin{abstract}
Summary
Attention is drawn to the fact that in a number of types of short-limbed dwarfism a precise diagnosis can be made in the neonatal period. Examples are given and the prognostic and genetic implications are discussed. It is important to be able to advise parents of the likely outlook for the infant and of the genetic implication. Early diagnosis is therefore not merely an academic exercise.

\section{Introduction}

When Rathbun (1948) first described neonatal hypophosphatasia he discussed three conditions of differential diagnosis. These consisted of osteogenesis imperfecta, achondroplasia and renal hyperparathyroidism. Since then a number of other conditions have been defined on a clinical, radiological and genetic basis (Tables 1 and 2). Such conditions are not excessively rare if sought. Ryan and Kozlowski (1971) found nineteen cases of bone dysplasia in consecutive radiographs of 109 infants dead on delivery. When a case of neonatal hypophosphatasia occurred in the authors' unit they were able to include thirteen conditions in the differential diagnosis. They are here described together with prognosis and genetic implications.
\end{abstract}

\section{Achondroplasia}

Achondroplasia is the prototype of true bone dysplasia (Rubin, 1963) and it is the best described form of neonatal dwarfism. Its incidence per one million people was found to be fifteen in the United States (Potter and Coverstone, 1948), twenty-three in Denmark (Mørch, 1941) and 283 in Northern Ireland (Stevenson, 1957). It is inherited as an autosomal dominant but over $90 \%$ of cases are fresh mutations especially with elderly parents (Barr and Forfar, 1973). Harris and Patton (1971) in their series found that the mutation rate was not greater than 1 in 100,000 . Its incidence in twins is extremely rare.

Clinically the condition may be recognizable at birth but often it is not, as the features of proximal limb shortening, large head, depressed nasal bridge and prominent forehead may be poorly developed.
Harris and Patton (1971) reviewed seventeen stillborn or early neonatal deaths originally diagnosed as achondroplastics and showed that in ten of these cases the diagnosis should have been thanatophoric dwarfism. This supports the view that achondroplasia has been over diagnosed at birth and that the severely affected cases are, in fact, some other type of lethal neonatal dwarfism.

\section{Achondrogenesis}

This was first described under the title of anosteogenesis (Parenti, 1936) as it was thought to be a variety of osteogenesis imperfecta. Fraccaro (1952) first used the term 'achondrogenesis' because of marked retardation of ossification. Parental consanguinity (Saldino, 1971) and multiple affected siblings (Houston, Awen and Kent, 1972) have been reported. The role of teratogenic agents is speculative as a case of achondrogenesis following maternal thalidomide ingestion has been described (Jurczok and Schollmeyer, 1962). Hydramnios is a frequent complication of the pregnancy and achondrogenic infants are usually premature and stillborn. It is a rare condition and is characterized at birth by extremely short limbs, large head, swollen abdomen, poor ossification of bones generally and essentially no neck (Fig. 1). Harris, Patton and Barson (1972) described two siblings under the title of 'pseudoachondrogenesis with fractures' which is representative of a different type of achondrogenesis and resembling the siblings described by Houston et al. (1972). This particular variety is now known as 'Harris and Houston' type of achondrogenesis (Fig. 2). The presence of fractures is the point of differentiation between the two types of this condition.

\section{Asphyxiating thoracic dystrophy}

Jeune, Béraud and Carron (1955) first described this condition. It is characterized by extemely short ribs, variable degree of shortening of limbs and fingers and occasionally by polydactyly. The thorax is narrow and immobile. Hereditary nephritis leading to death has been reported (Shokeir, Houston and Awen, 1971). 
TABLE 1. Clinical differences

\begin{tabular}{|c|c|c|c|c|c|}
\hline Type & Family history & Antenatal & $\begin{array}{l}\text { Part of limbs } \\
\text { involved }\end{array}$ & $\begin{array}{c}\text { Associated } \\
\text { abnormalities }\end{array}$ & Inheritance \\
\hline Achondroplasia (mutant) & - & - & Proximal & $\begin{array}{l}\text { Enlarged head, de- } \\
\text { pressed nasal bridge, } \\
\text { hands and feet short } \\
\text { and broad }\end{array}$ & $\begin{array}{l}\text { Autosomal } \\
\text { dominant }\end{array}$ \\
\hline Achondrogenesis & $\begin{array}{l}\text { Parental consan- } \\
\text { guinity }\end{array}$ & $\begin{array}{l}\text { Hydramnios } \\
\text { stillbirth }\end{array}$ & $\begin{array}{l}\text { Both proximal } \\
\text { and distal }\end{array}$ & $\begin{array}{l}\text { Large head, essentially } \\
\text { no neck, swollen } \\
\text { abdomen }\end{array}$ & $\begin{array}{l}\text { Autosomal } \\
\text { recessive }\end{array}$ \\
\hline $\begin{array}{l}\text { Asphyxiating thoracic } \\
\text { distal }\end{array}$ & - & - & Distal & $\begin{array}{l}\text { Extremely short ribs, } \\
\text { narrow and immobile } \\
\text { thorax, polydactyly, } \\
\text { hereditary nephritis }\end{array}$ & $\begin{array}{l}\text { Autosomal } \\
\text { recessive }\end{array}$ \\
\hline Chondrodysplasia punctata & - & - & $\begin{array}{l}\text { Proximal and } \\
\text { distal }\end{array}$ & $\begin{array}{l}\text { Flexion contracture of } \\
\text { joints, cataracts, } \\
\text { ectodermal changes, } \\
\text { mental deficiency }\end{array}$ & $\begin{array}{l}\text { Autosomal } \\
\text { recessive }\end{array}$ \\
\hline $\begin{array}{l}\text { Chondro-ectodermal } \\
\text { dysplasia (Ellis-Van } \\
\text { Creveld syndrome) }\end{array}$ & - & - & Distal & $\begin{array}{l}\text { Thoracic dystrophy, } \\
\text { polydactyly, con- } \\
\text { genital heart, ecto- } \\
\text { dermal changes }\end{array}$ & $\begin{array}{l}\text { Autosomal } \\
\text { recessive }\end{array}$ \\
\hline Diastrophic dwarf & - & - & Distal & $\begin{array}{l}\text { Marked talipes equino- } \\
\text { varus, resembles } \\
\text { arthrogryposis, 'hitch- } \\
\text { hiker' thumb }\end{array}$ & Autosomal \\
\hline $\begin{array}{l}\text { Homozygous achondro- } \\
\text { plasia }\end{array}$ & $\begin{array}{l}\text { Both parents } \\
\text { achondroplastic }\end{array}$ & - & Proximal & $\begin{array}{l}\text { Large head, depressed } \\
\text { nasal bridge, frontal } \\
\text { bossing, early death }\end{array}$ & $\begin{array}{l}\text { Autosomal } \\
\text { dominant }\end{array}$ \\
\hline Hypophosphatasia & $\begin{array}{l}\text { Parental consan- } \\
\text { guinity }\end{array}$ & $X$-ray diagnostic & $\begin{array}{l}\text { Proximal and } \\
\text { distal }\end{array}$ & $\begin{array}{l}\text { Soft skull bones, } \\
\text { marked angulation } \\
\text { and deformities of } \\
\text { long bones }\end{array}$ & $\begin{array}{l}\text { Autosomal } \\
\text { recessive }\end{array}$ \\
\hline $\begin{array}{l}\text { Lymphopenic agamma- } \\
\text { globulinaemia with short- } \\
\text { limbed dwarfism }\end{array}$ & - & - & Proximal & $\begin{array}{l}\text { Features of achondro- } \\
\text { plasia, lymphopenia, } \\
\text { agammaglobulin- } \\
\text { aemia, early death }\end{array}$ & Not known \\
\hline Metatrophic dwarf & - & - & $\begin{array}{l}\text { Proximal and } \\
\text { distal }\end{array}$ & $\begin{array}{l}\text { Long narrow thorax, } \\
\text { caudal appendage, } \\
\text { swollen joints }\end{array}$ & $\begin{array}{l}\text { Autosomal } \\
\text { recessive }\end{array}$ \\
\hline Osteogenesis imperfecta & Blue sclera & $X$-ray diagnostic & $\begin{array}{l}\text { Proximal and } \\
\text { distal }\end{array}$ & Soft skull, blue sclera & $\begin{array}{l}\text { Autosomal } \\
\text { dominant } \\
\text { recessive }\end{array}$ \\
\hline $\begin{array}{l}\text { Spondylo-epiphyseal } \\
\text { dysplasia congenita }\end{array}$ & - & - & $\begin{array}{l}\text { Proximal and } \\
\text { distal }\end{array}$ & $\begin{array}{l}\text { Myopia, retinal detach- } \\
\text { ment, cataract, cleft } \\
\text { palate }\end{array}$ & $\begin{array}{l}\text { Autosomal } \\
\text { dominant }\end{array}$ \\
\hline Thanatophoric dwarf & $\begin{array}{l}\text { Parental consan- } \\
\text { guinity }\end{array}$ & $\begin{array}{l}\text { Hydramnios, } \\
\text { weak fetal move- } \\
\text { ments, stillbirth, } \\
\text { X-ray diagnostic }\end{array}$ & Proximal & $\begin{array}{l}\text { Redundant skin folds, } \\
\text { limbs abducted and } \\
\text { externally rotated, } \\
\text { large head with frontal } \\
\text { prominence }\end{array}$ & $\begin{array}{l}\text { Autosomal } \\
\text { recessive }\end{array}$ \\
\hline
\end{tabular}


TABLE 2. Radiographic differences

\begin{tabular}{|c|c|c|c|c|c|}
\hline Type & Spine & Limbs & Pelivs & Thorax, ribs & Skull \\
\hline $\begin{array}{l}\text { Achondroplasia } \\
\text { (mutant) }\end{array}$ & $\begin{array}{l}\text { Narrow inter- } \\
\text { pedicular distance } \\
\text { of lower lum- } \\
\text { bar vertebrae }\end{array}$ & $\begin{array}{l}\text { Proximal bones } \\
\text { short, ball and } \\
\text { socket appear- } \\
\text { ance of meta- } \\
\text { physes }\end{array}$ & $\begin{array}{l}\text { Narrow sacrum } \\
\text { and sciatic notch }\end{array}$ & $\begin{array}{l}\text { Thorax long and } \\
\text { narrow }\end{array}$ & $\begin{array}{l}\text { Large vault, } \\
\text { small base and } \\
\text { foramen magnum }\end{array}$ \\
\hline Achondrogenesis & $\begin{array}{l}\text { Poorly mineralized } \\
\text { and ossified }\end{array}$ & $\begin{array}{l}\text { Marked shorten- } \\
\text { ing, poorly } \\
\text { mineralized }\end{array}$ & Poorly mineralized & $\begin{array}{l}\text { Short ribs, clavicles } \\
\text { disproportionately } \\
\text { long }\end{array}$ & $\begin{array}{l}\text { Poorly mineral- } \\
\text { ized, otherwise } \\
\text { normal }\end{array}$ \\
\hline $\begin{array}{l}\text { Asphyxiating thoracic } \\
\text { dystrophy }\end{array}$ & Normal & $\begin{array}{l}\text { Variable short- } \\
\text { ening }\end{array}$ & $\begin{array}{l}\text { Hypoplastic iliac } \\
\text { hook-shaped } \\
\text { sciatic notch }\end{array}$ & $\begin{array}{l}\text { Extremely short } \\
\text { horizontal ribs }\end{array}$ & Normal \\
\hline $\begin{array}{l}\text { Chondrodysplasia } \\
\text { punctata }\end{array}$ & $\begin{array}{l}\text { Punctate calcifica- } \\
\text { tions of inter- } \\
\text { vertebral discs }\end{array}$ & $\begin{array}{l}\text { Both proximal and } \\
\text { distal shortening, } \\
\text { puncatate calcifi- } \\
\text { cations of joint } \\
\text { capsules and } \\
\text { epiphyses }\end{array}$ & - & Normal & Craniostenosis \\
\hline $\begin{array}{l}\text { Chondro-ectodermal } \\
\text { dysplasia (Ellis-Van } \\
\text { Creveld syndrome) }\end{array}$ & Normal & $\begin{array}{l}\text { Short distal bones, } \\
\text { hypoplastic } \\
\text { terminal phalanges, } \\
\text { carpal and tarsals } \\
\text { fused into solid } \\
\text { masses }\end{array}$ & $\begin{array}{l}\text { Reduced height of } \\
\text { bones }\end{array}$ & Short ribs & Normal \\
\hline Diastrophic dwarf & $\begin{array}{l}\text { Hypoplastic } \\
\text { cervical verte- } \\
\text { brae }\end{array}$ & $\begin{array}{l}\text { Hypoplastic first } \\
\text { metacarpal }\end{array}$ & $\begin{array}{l}\text { Acetabular dys- } \\
\text { plasia }\end{array}$ & Long thorax & Normal \\
\hline $\begin{array}{l}\text { Homozygous } \\
\text { achondroplasia }\end{array}$ & $\begin{array}{l}\text { Flattening of } \\
\text { vertebrae }\end{array}$ & Markedly short & Small iliacs & Short ribs & Large, small base \\
\hline Hypophosphatasia & Normal & $\begin{array}{l}\text { Appearance of } \\
\text { severe rickets }\end{array}$ & Normal & $\begin{array}{l}\text { Marked costo- } \\
\text { chondral bead- } \\
\text { ing }\end{array}$ & $\begin{array}{l}\text { Little or no bone } \\
\text { material }\end{array}$ \\
\hline Metatrophic dwarf & Flat vertebrae & $\begin{array}{l}\text { Metaphyses mark- } \\
\text { edly flared, } \\
\text { enlarged and } \\
\text { irregular }\end{array}$ & $\begin{array}{l}\text { Crescent-shaped } \\
\text { iliac crests }\end{array}$ & $\begin{array}{l}\text { Long thorax, } \\
\text { short ribs }\end{array}$ & Normal \\
\hline $\begin{array}{l}\text { Osteogenesis imper- } \\
\text { fecta }\end{array}$ & Shallow vertebrae & $\begin{array}{l}\text { Thick-thin bones, } \\
\text { stunted, deformed }\end{array}$ & Normal & Deformities & Poorly ossified \\
\hline $\begin{array}{l}\text { Spondylo-epiphyseal } \\
\text { displasia congenita }\end{array}$ & $\begin{array}{l}\text { Hypoplastic odon- } \\
\text { toid }\end{array}$ & $\begin{array}{l}\text { Short, bowing of } \\
\text { femora }\end{array}$ & Small iliac wings & Bell-shaped thorax & Normal \\
\hline Thanatophoric dwarf & $\begin{array}{l}\text { Flat vertebrae, } \\
\text { deep discs }\end{array}$ & $\begin{array}{l}\text { Markedly short, } \\
\text { bowing of femur }\end{array}$ & Short iliacs & $\begin{array}{l}\text { Short ribs, wide } \\
\text { anterior ends }\end{array}$ & $\begin{array}{l}\text { Enlarged, short } \\
\text { base, premature } \\
\text { fusion of } \\
\text { coronal and } \\
\text { lamboidal } \\
\text { sutures }\end{array}$ \\
\hline
\end{tabular}

\section{Chondro-ectodermal dysplasia}

This condition was described in 1940 by Ellis and Van Creveld. It is a complex dysplasia in which skeletal defects are associated with ectodermal anomalies affecting hair, teeth and nails, and congenital heart disease is common. The shortening of limbs in this condition is the reversal of achondroplasia in that it is the distal parts of the limbs which are shortened rather than the proximal (Fig. 3) and polydactyly of fingers and toes is commonly found.

\section{Chondrodysplasia punctata}

These infants are recognizable at birth as dwarfs with short limbs. Radiologically punctate calcifications are found in the epiphyses, joint capsules, trachea, larynx, hyoid, intervertebral discs and in 


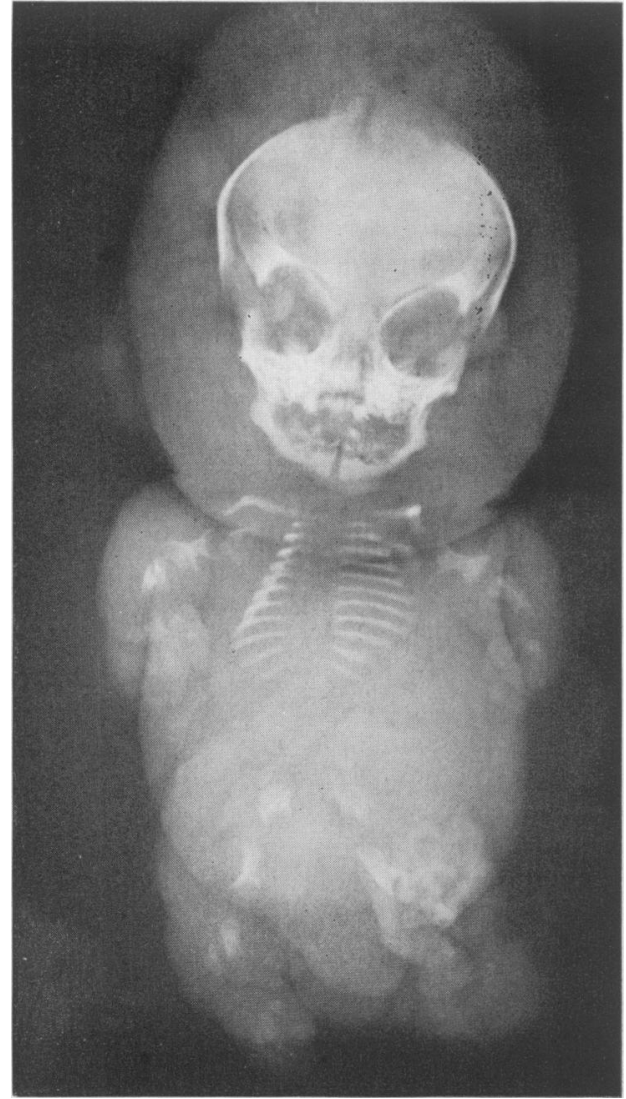

FIG. 1. A stillborn infant with achondrogenesis showing oedematous soft tissue, virtual absence of ossification of bones and micromelia.

rhizomelic type proximal limb bone shortening (Fig. 4).

\section{Diastrophic dwarf}

This term was coined by Lamy and Maroteaux (1960) for achondroplastic-like dwarfs with twisted lower extremities and varying degrees of scoliosis. The other abnormalities described are contracture of joints, dislocation of hips, knees, radial heads and superficial resemblance to arthrogryposis. The long bones are short. The thumbs are displaced proximally and the first metacarpal bone is hypoplastic. The hypoplasia of the mid-cervical vertebrae is a characteristic radiographic feature.

\section{Homozygous achondroplasia}

This is extremely rare and is lethal. The affected infant dies within the first few days or weeks of life. The overall body proportions of the infant are midway between those of a thanatophoric dwarf and those of an infant with classical achondroplasia

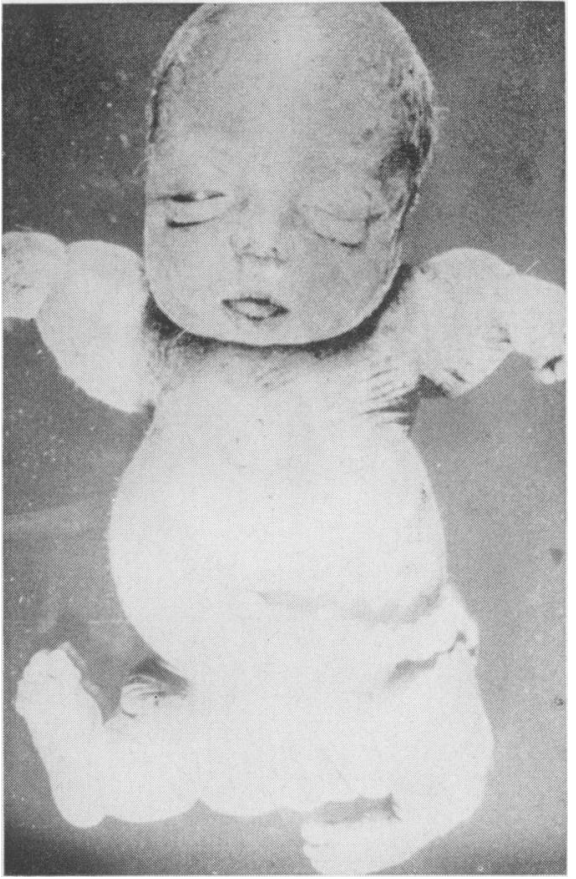

FIG. 2. 'Harris and Houston' type of achondrogenesis.

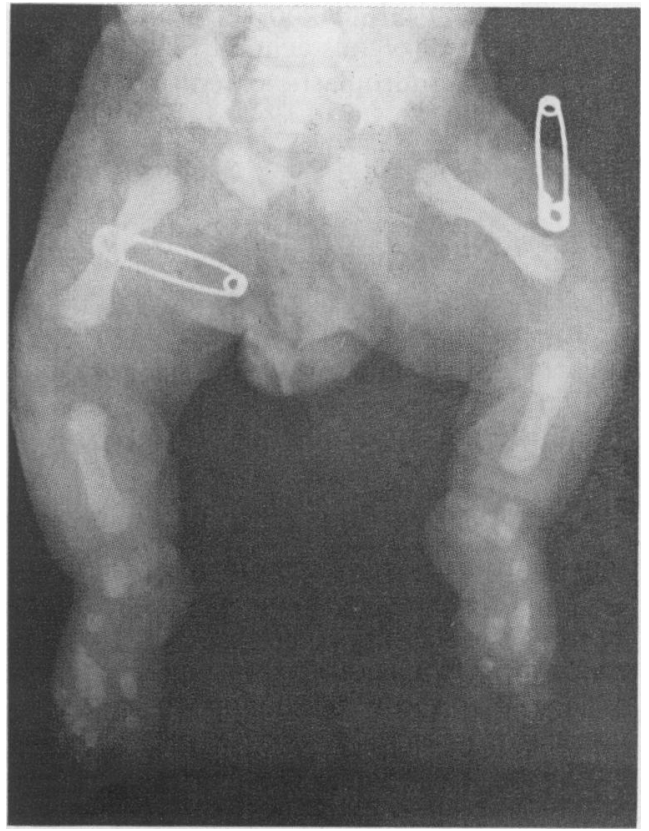

FIG. 3. Three-day-old infant with chondro-ectodermal dysplasia. 


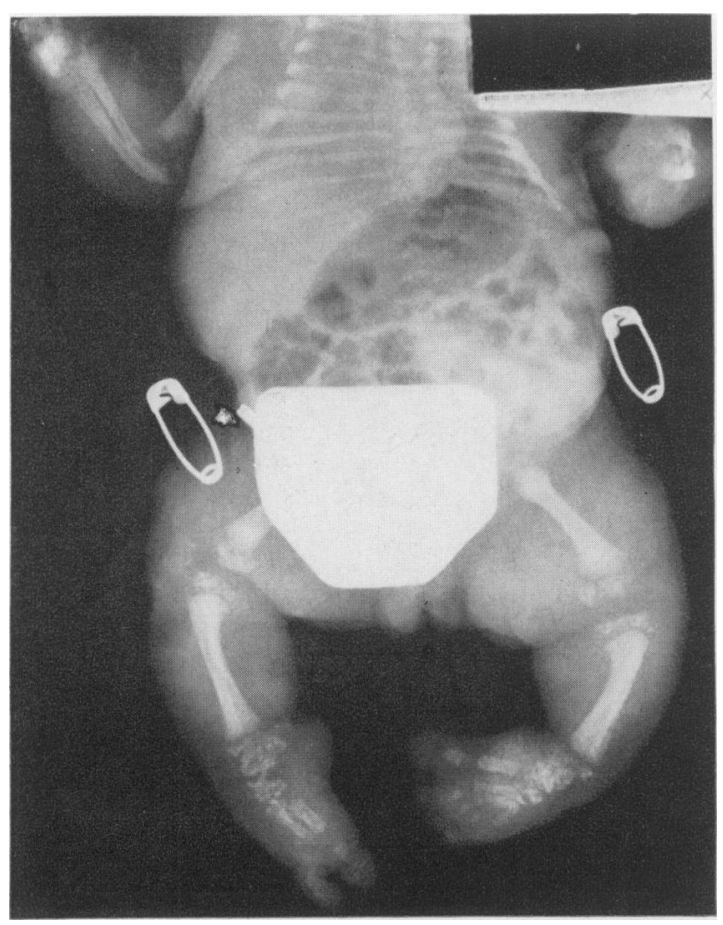

Fig. 4. A newborn infant with rhizomelic type of chondrodysplasia punctata.

(Fig. 5). The clinical diagnosis is made without difficulty as a homozygous achondroplast is the offspring of two achondroplastic parents.

\section{Hypophosphatasia}

This is an autosomal recessive condition.

The term 'hypophosphatasia' was used for the first time by Rathbun (1948) to designate an osteoblastic condition with low serum alkaline phosphatase. There are three salient features-abnormal mineralization of bone, increased urinary excretion of phosphoethanolamine and diminished alkaline phosphatase activity. Fraser (1957) described three different categories depending on the age of onset: newborn, infants and children. The newborn type is the most severe (Figs 6 and 7) and carries the worst prognosis. Hypercalcaemia is a common complication presumably due to accumulation of calcium in the blood as it fails to be incorporated into bone because of absent or low alkaline phosphatase activity. Dent (1956) maintained that the hypercalcaemia in hypophosphatasia was due to hypersensitivity to vitamin $D$. This hypercalcaemia can be complicated by nephrocalcinosis which can contribute to some of the fatal outcome.

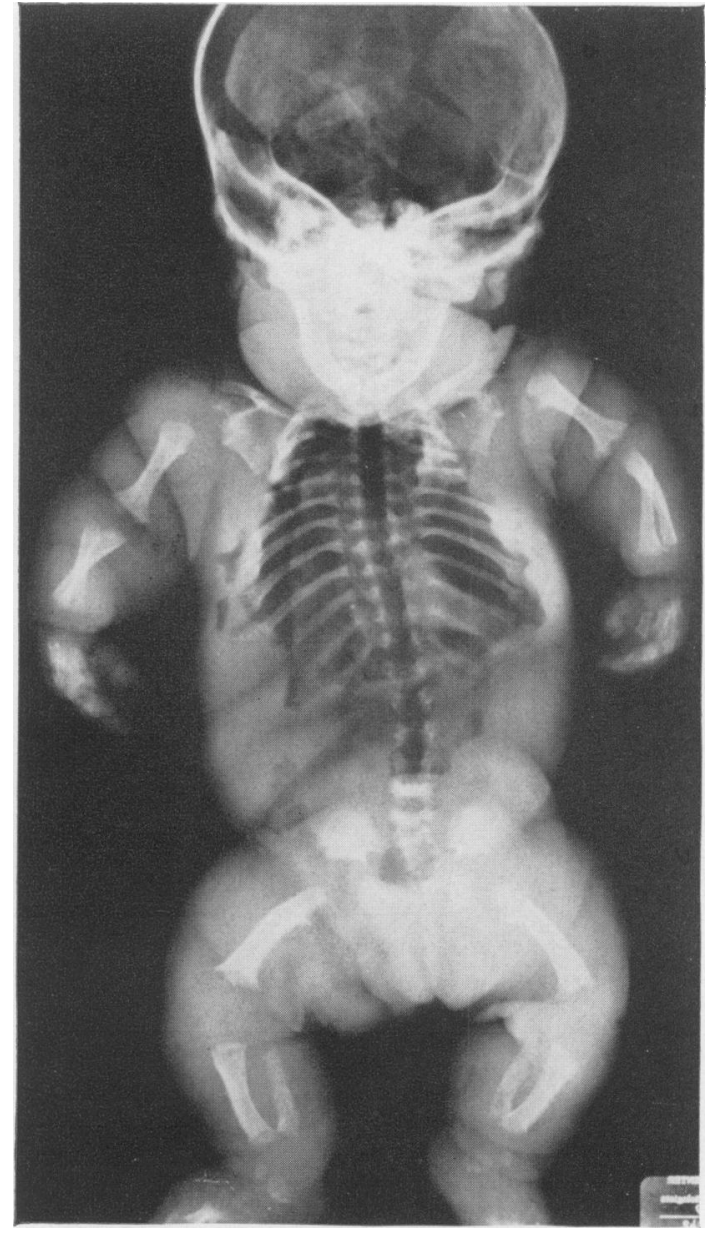

FIG. 5. Two-day-old infant with homozygous achondroplasia.

\section{Lymphopenic agammaglobulinaemia with short-limbed dwarfism}

McKusick and Cross (1966) first described a patient with Swiss-type agammaglobulinaemia and a skeletal disorder resembling achondroplasia but they thought the sketetal disorder had no relationship to the agammaglobulinaemia. A few months later Davis (1966) described a newborn female infant with achondroplasia and Swiss-type agammaglobulinaemia. He concluded that because of the rarity of both conditions their concurrence was due to genetic association and not simply to chance. The subsequent recognition of isolated cases of this nature (Fulginiti et al., 1967; Alexander and Dunbar, 1968) have given support to Davis's assumption.

\section{Metatrophic dwarf}

This term 'metatrophic' (which means 'variable') 


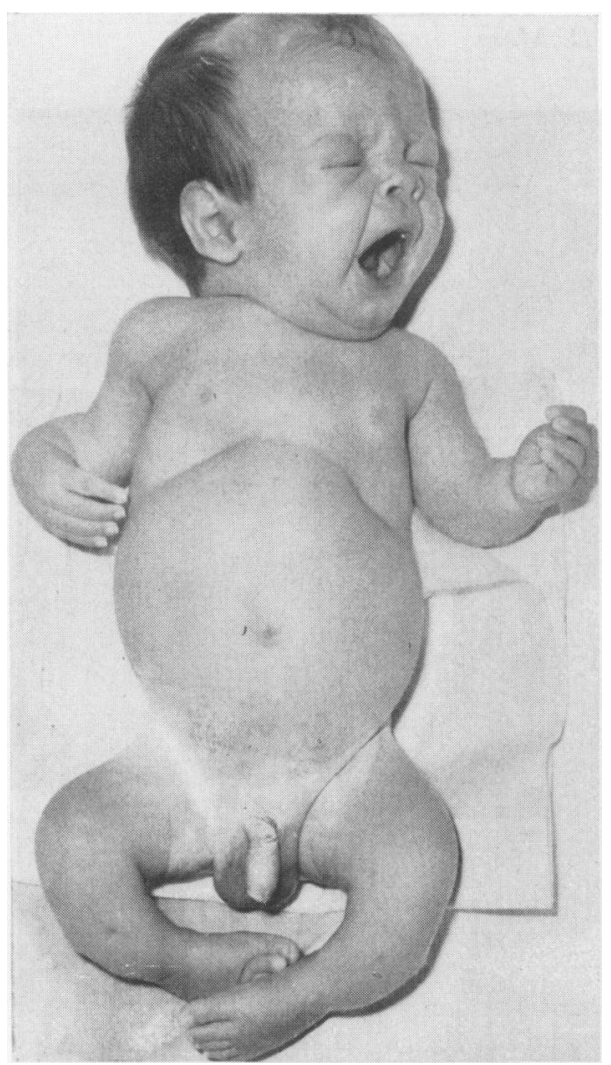

FIG. 6. Day-old infant with neonatal hypophosphatasia showing large head, narrow thorax, bowing of legs and cutaneous dimples on outer aspects of legs.

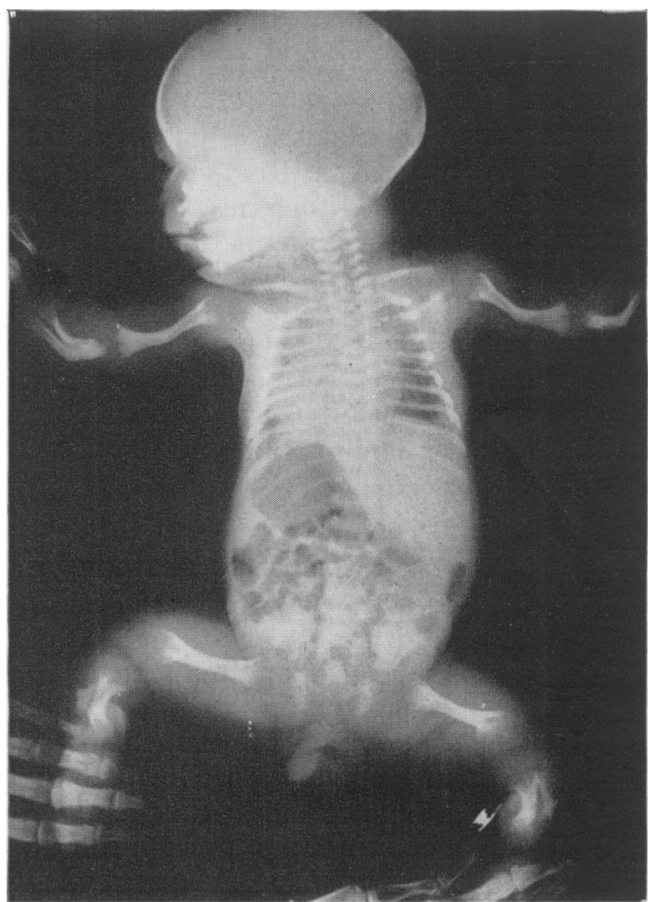

FIG. 7. Day-old infant with neonatal hypophosphatasia showing demineralization simulating severe rickets.

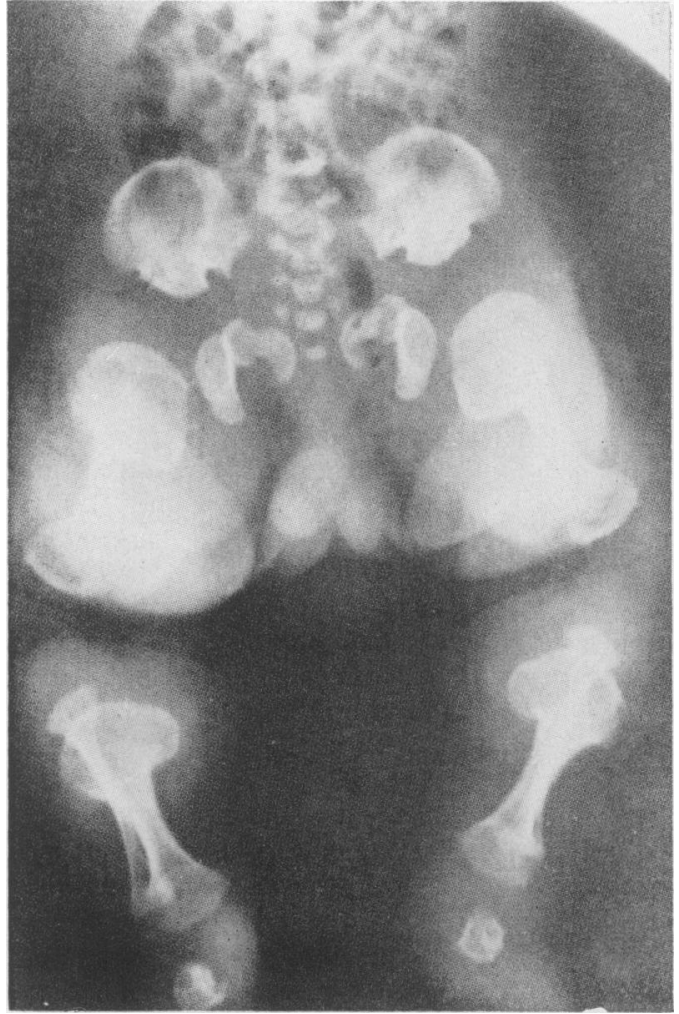

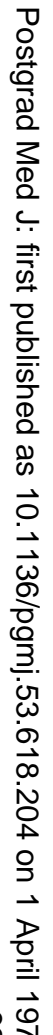

FIg. 8. Metatrophic dwarf showing expansion of all 0 metaphyses, dumb-bell shaped long bones and flattening of vertebrae.

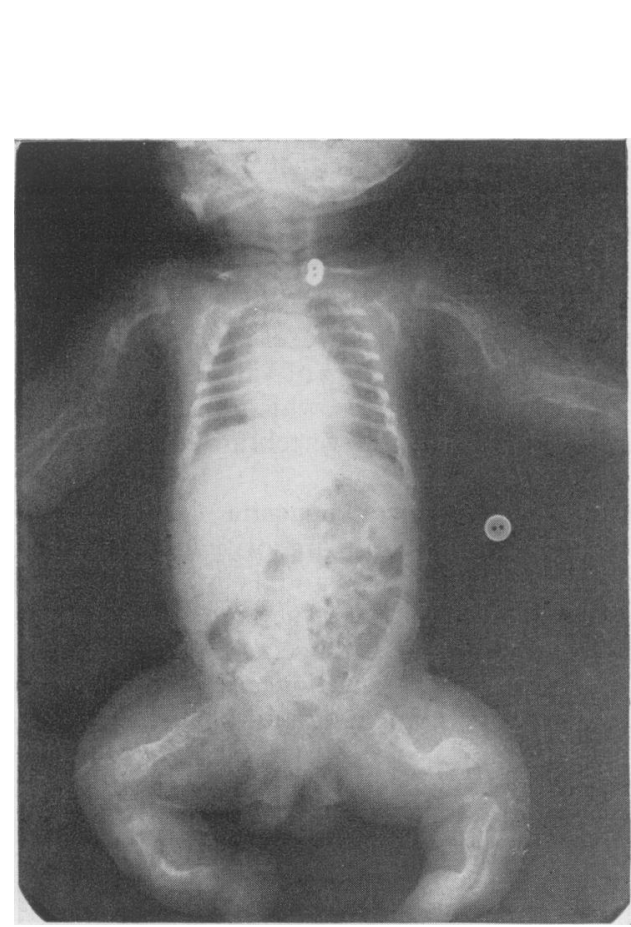

FIG. 9. Osteogenesis imperfecta congenita. 


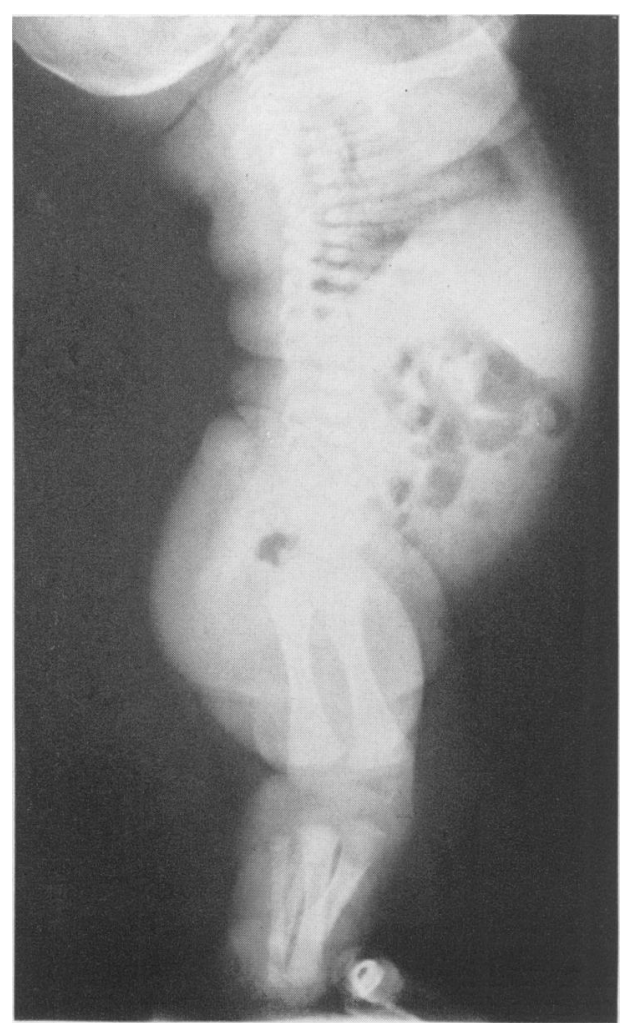

FIG. 10. Spondylo-epiphyseal dysplasia congenita showing shortening of ribs and long bones, flattening of thoracic vertebrae posteriorly and hypoplastic odontoid.

was defined by Maroteaux, Spranger and Wiedemann (1966) for a condition characterized by variation in the clinical picture with age. Initially they superficially resemble achondroplastics with limbs shorter than trunk; later, the proportions reverse with more shortening of the trunk than limbs and bear resemblance to Morquio's disease. The skeletal radiographs show expansion of all the metaphyses, shortening of long bones which become dumb-bell shaped and flattening of vertebral bodies (Fig. 8).

\section{Osteogenesis imperfecta congenita}

This condition in the majority of cases results from sporadic mutation and is inherited as autosomal dominant. The severe neonatal type indicates a recessive mode of inheritance. It is characterized by multiple fractures of long bones which consequently become deformed, angulated and short (Fig. 9).

\section{Spondylo-epiphyseal dysplasia congenita}

This condition was first described by Spranger and Wiedemann (1966). It selectively affects vertebrae, epiphyses of long bones and occasionally adjacent

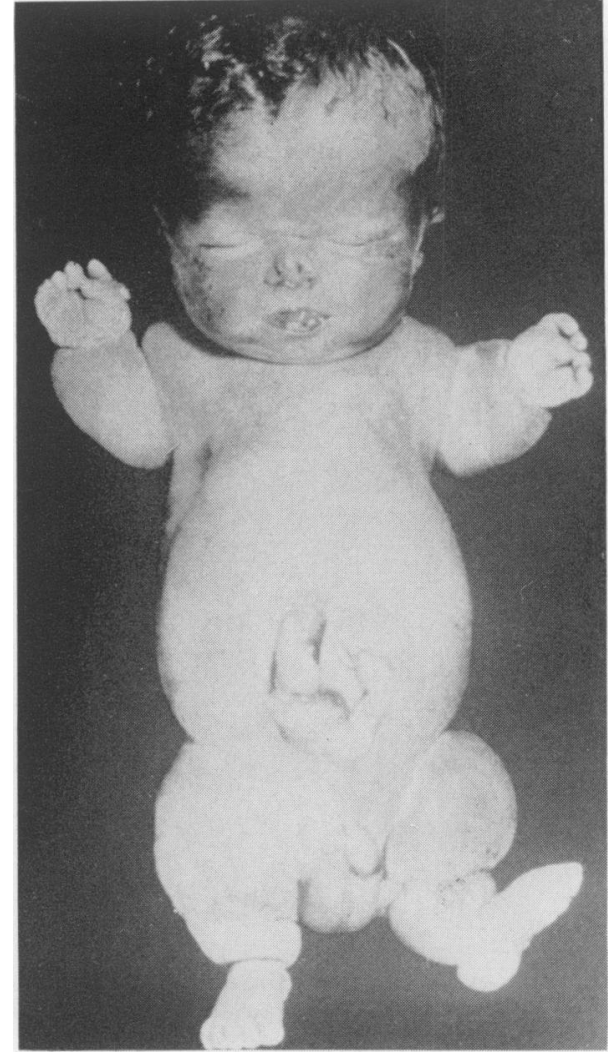

Fig. 11. Thanatophoric dwarf.

metaphyses. The associated clinical abnormalities are: severe myopia, retinal detachment, cataracts, deafness and cleft palate. Roaf, Longmore and Forrester (1967) reported four cases of a syndrome comprising bone dysplasia, retinal detachment and deafness. These were probably cases of spondyloepiphyseal dysplasia. There are six types of spondyloepiphyseal dysplasia distinguishable on clinical, genetic and radiological grounds. It is inappropriate to discuss all here. The skeletal radiograph (Fig. 10) shows the abnormalities that are found in the congenital variety.

\section{Thanatophoric dwarf}

Maroteaux, Lamy and Robert (1967) first reported this condition which is the commonest cause of neonatal deaths amongst short-limbed dwarfs. The title means 'death bearing'. Harris and Patton (1971) reviewed seventeen stillborn and early neonatal deaths originally diagnosed as achondroplasia and showed that in ten of these the diagnosis should have been thanatophoric dwarf. The clinical appearance is characteristic (Fig. 11) and consists of very short 
limbs, redundant skin folds, limbs held in abduction and external rotation, a large head and depressed nasal bridge.

\section{Conclusions}

It is now possible to make an early and precise diagnosis in a number of different types of shortlimbed dwarfs. This is of importance for prognosis and genetic counselling.

\section{Acknowledgments}

The authors are grateful to Dr R. Harris and the Journal of Clinical Genetics for permission to reproduce two figures (Figs 2 and 11). They gratefully acknowledge permission from Dr R. M. Saldino for the illustrations (Figs 1, 3, 4, 5, 8, 10) obtained from Medical Radiography, and photography published by Radiography Markets Divisions, Eastman Kodak Company.

The authors would like to thank Mrs M. E. Hunt for her invaluable help in typing the manuscript.

\section{References}

Alexander, W.J. \& Dunbar, J.S. (1968) Unusual bone changes in thymic alymphoplasia. Annals of Radiology, $11,389$.

BarR D.G.D. \& Forfar, J.O. (1973) Textbook of Paediatrics. Churchill Livingstone, London and Edinburgh.

Davis, J.A. (1966) A case of Swiss type of agammaglobulinaemia and achondroplasia. British Medical Journal, $2,1371$.

DENT, C.E. (1956) Bone structure and metabolism. In: Ciba Foundation Symposium, p. 266. Churchill, London.

Ellis, R.W.B. \& Van Creveld, S. (1940) Syndrome characterized by ectodermal dysplasia, polydactyly, chondrodysplasia and congenital morbus cordis: report of 3 cases. Archives of Disease in Childhood, 15, 65.

Fraccaro, M. (1952) Contributo allo studio delle malattie del mesenchima osteopoitico: l'achondrogenesi. Folia hereditaria et pathologica (Milano) 1, 190.

Fraser, D. (1957) Hypophosphatasia. American Journal of Medicine, 730.

Fulginiti, V.A., Hathaway, W.E., Pearlman, D.S. \& KeMP, C.H. (1967) Agammaglobulinaemia and achondroplasia. British Medical Journal, 2, 1371.

Harris, R. \& PATton, J.T. (1971) Achondroplasia and thanatophoric dwarfism in newborn. Clinical Genetics, 2, 61 .

Harris, R., Patton, J.T. \& Barson, A.J. (1972) Pseudoachondrogenesis with fractures. Clinical Genetics, 3, 435.

Houston, C.S., Awen, C.F. \& Kent, H.P. (1972) Fatal neonatal dwarfism. Journal of the Canadian Association of Radiologists, 23, 45.

Jeune, M., Béraud, C. \& Carron, R. (1955) Dystrophie thoracique asphyxiante de caractère familial. Archives françaises de pédiatrie, $12,886$.

Jeune, M., Béraud, C. \& Carron, R. (1962) Zur frage des gehauften Auftretens von Extremitätenmissbildungen bei Neugeborenen. Geburtshilfe und Frauenheilkunde, 22, 400.

Jurczok, F. \& Schollmeyer, R. (1962) Zur Frage des gehauften Auftretens von Extremitätenmissbildungen bei Neugeborenen, Geburtshilfe und Frauenheilkunde, 22, 400.

Lamy, M. \& Maroteaux, P. (1960) Diastrophic nanism. Presse Médicale, 68, 1977.

MCKusick, V.A. \& CRoss, H.E. (1966) Ataxia telangiectasia and Swiss type agammaglobulinaemia. Journal of the American Medical Association, 195, 739.

Maroteaux, P., Lamy, M. \& Robert, J.M. (1967) Le nanisme thanatopore. Presse Médicale, 75, 2519.

Maroteaux, P., SPranger, J. \& WiedemanN, H.R. (1966) Der metatropische Zwergwuchs. Archiv für Kinderheilkunde, 173, 211.

MøRCH, E.T. (1941) Chondrodystrophic Dwarfs in Denmark. Ejnar Munksgaard, Copenhagen.

PARENTI, G.C. (1936) La anosteogenesi (una varietà della osteogenesi imperfetta). Pathologica. Genova, 28, 447.

Potter, E.L. \& Coverstone, V.A. (1948) Chondrodystrophy foetalis. American Journal of Obstetrics and Gynecology, 56, 790.

Rathbun, J.C. (1948) 'Hypophosphatasia'. New developmental anomaly. American Journal of Diseases of Children, $75,822$.

Roaf, R., Longmore, J.B. \& Forrester, R.M. (1967) A childhood syndrome of bone dysplasia, retinal detachment and deafness. Developmental Medicine and Child Neurology, 9, 464.

Rubin, P. (1963) Achondroplasia versus pseudoachondroplasia. Radiologic Clinics of North America, 1, 621.

RYAN, J. \& KOZlowSKI, K. (1971) Australian Radiation Records, 15, 213.

SALDINo, R.M. (1971) Lethal short limbed dwarfism: achondrogenesis and thanatophoric dwarfism. American Journal of Roentgenology, 112, 185.

Shokeir, M.H.K., Houston, C.S. \& Awen, C.F. (1971) Asphyxiating thoracic chondrodystrophy. Association with renal disease and evidence for possible heterozygous expression. Journal of Medical Genetics, 8, 107.

Spranger, J. \& Wiedeman, H.R. (1966) Dysplasia spondyloepiphysaria congenita. Helvetica paediatrica acta, 21, 598.

Stevenson, A.C. (1957) Achondroplasia: an account of the condition in Northern Ireland. American Journal of Human Genetics, 9, 8. 